\title{
Macedonian Intercalary Months and the Era of Azes
}

\author{
Harry Falk and Chris Bennett \\ Freie Universität Berlin - University of California at San Diego
}

\begin{abstract}
The Azes era was identified with the Vikrama era when a date in a year "of King Azes the Great" was read for the first time on the Indravarman casket in 1978, making more likely what had been suspected before. Doubts about this identification have been brought forward occasionally.

The present study starts from a new reading of the so-called Trașaka reliquary. In addition to its month called "intercalary Gorpiaios" a year number could be read as 172. This particular month is only intercalary in the Arsacid model of the Macedonian calendar and here it occurs only once in every 19 year cycle. Starting from a Vikrama year 1, year 172 would not produce an intercalary Gorpiaios. Starting from those years which in fact produced one, the beginning of the era of Azes must be shifted earlier or later than the Vikrama starting point. A series of comparisons with the so-called Yavana era and the Arsacid era led to a new start of the Azes era in 48/7 (autumn-based year) or $47 / 6$ $\mathrm{BC}$ (spring-based year). This sheds light also on the nature of the starting point of the Kanișka era.
\end{abstract}

Keywords: Hellenism; time reckoning; intercalary months; Gandhara; epigraphy; Arsacid calendar; Macedonian calendar; eras of Azes, Kaniska, Yavana. 


\section{Introduction}

King Azes has been known since the days of Charles Masson, who collected coins in the 1830s in Gandhara proper and eastern Afghanistan. These coins are inscribed in a Greek genitive AZOY, and on the reverse, again in a genitive form, as ayasa in Kharosthī. The respective Greek nominative *AZOS has not surfaced so far. The Kharosthī form ayasa was first found in combination with a date comprising year, month and day on the Taxila silver scroll. ${ }^{1}$ As early as 1914, MARSHALL suggested that this date followed an era named after king aya. While MARSHALL considered the possibility, RAPSON was the first scholar who firmly equated this era with the Vikrama era, starting in 58/57 $\mathrm{BC}^{2}$ Other solutions for the word ayasa were offered as well, until in 1978 BAILEY published the Indravarman reliquary, in which the era was given not as ayasa, but as maharajasa ayasa. Instantly, the meaning of ayasa was beyond dispute. Three scholars (BIVAR 1981, FUSSMAN 1980, SALOMON 1982) almost immediately referred to this new evidence and it became customary to speak of the "proof that the era of Azes is the Vikrama era". In fact, all that had been proved was that aya was King Azes. The conjectural nature of the linkage between the aya era and Vikrama samvat was unaffected by the new evidence.

Nonetheless, the equation of Azes' era and the Vikrama era did not appear to be blatantly wrong and was defended for practical reasons by all - except for two scholars in London, Elizabeth ERRINGTON and Joe CRIBB.

\section{The "Trașaka" Reliquary}

The pivotal starting point for the present study is found in two inscriptions preserved on the outside and inside of the same schist reliquary. The two texts were published by G. FUSSMAN in 1985, after which the object and the texts became known as the "Trasaka" reliquary. The letters are not very carefully incised and the scribes did not take much care that others could read the text.

1 Marshall 1914; KonOw 1929: 1xxxv, 70-73.

2 MARSHALl 1914: 977; RAPSON 1922: viii-ix, 581. 
This attitude has left us with one of the most ambiguous collection of Kharoșthī characters. FUSSMAN's readings are all possible, but, as usual with carelessly written Kharoșthī, many other readings are possible. A new study suffers from the fact that the object seems to have disappeared from public view and every reading must rely on the photographs provided in FUSSMAN 1985, plates a-b. Each one shows a bright spot where the room light was reflected, and at those places the readings are even more insecure than at others. Since the boost which FUSSMAN's studies of Kharosthī texts provided for this branch of epigraphy in the last two or three decades of the last century, many more texts have become known, particularly in the form of birch-bark manuscripts. Our knowledge of Kharosthi today profits from the many insights of that period but can draw on more recent results from a wide body of scholars. It is no wonder, therefore, that new editions are possible, and in some cases even necessary. A new edition of the first text is in the press; here, only those parts are dealt with which directly concern chronology.

\subsection{The first text}

The date formula on the first text on the outside of the lid reads:

sạ̣vatsaraye șapamcaüśá́adame masa ire daasa 20-1-1-1.

"In the year one hundred and fifty-six, in month Ira, on day 23."

This translation differs from FUSSMAN's reading on three points.

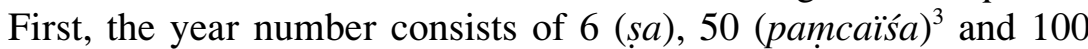
(śada). For reasons of chronological likelihood, FUSSMAN (1985: 38) understood the year number as equivalent to Skt. șatpañcāsattama and ended with a year 56. Later, this interpretation was corrected by SALOMON (1995: 131a) to "156". The second difference concerns the month Ira, which is otherwise unknown in Gandhara. FUSSMAN was looking for a Greek equivalent and found nothing in the Macedonian terminology. We propose to regard it as the Babylonian month Aiaru. The Babylonian month names

\footnotetext{
3 On the form and formation of pamcaïśa cf. BAUMS 2006: 38.
} 
Nisannu and Ululu are also found in Gandhara (see below). The development could have been Aiaru $\rightarrow{ }^{*}$ eru $\rightarrow *^{*}$ era $\rightarrow$ ira, in which case the phonological difficulties involved are not insurmountable.

The third difference concerns the day. FUSSMAN saw four strokes after the cipher for 20 . However, there are only three clear short verticals, whereas the sign following them starts as a vertical and ends in a left-bound bend. I take this to be a letter, i.e. the first letter of the man hitherto called trasaka. The most likely solution is a $n a$, so that trasaka would have to be renamed natrasaka, natasaka or similar. The same letter re-occurs in the second instance, where FUSSMAN took it for a $-s a$ attached to the previous word, resulting in a genitive obstructing the syntax of the whole sentence. The letter looks like a na again, rather clear in this case, followed by trasaka/tasaka. This way the sentence mentioning the two donors does justice to the shape of the letters and the syntax at the same time and in addition does away with four strokes denoting 4 , while a 4 in all other genuine cases comes as an Andrew's cross, $\mathrm{X}$.

\subsection{The second text}

The second text was read and translated as follows by FUSSMAN (1985: 37f.):

ime bhagavado śarira pratithapita sava-budhana pujae Apabrukas ${ }^{y}$ a Hiliupilaputras ${ }^{y} a$ (5) duasya [s]atriena Trama Gupriya yambulima mas a saste 4+4

"Ces (reliques) corporelles du Bienheureux ont été établies en l'honneur de tous les Buddha (par Trama, représentant de l'ambasadeur?) Apabruka, fils d'Héliophilos, mois de Gorpiaios intercalaire, jour 8."

This would be the only case where a date consists of just month and day, without the year number. The introduction is rather plain, speaking of "these relics" as something well-known. In fact, this is a re-dedication inscribed during a rebuilding or enlargement of the initial construction. The first term open for discussion is 
FUSSMAN's apabrukasa, where an equally nonsensical aprakhrakasa also seems possible. ${ }^{4}$ The letters are shown in outline in the first five characters of Fig. 1 to facilitate further proposals.

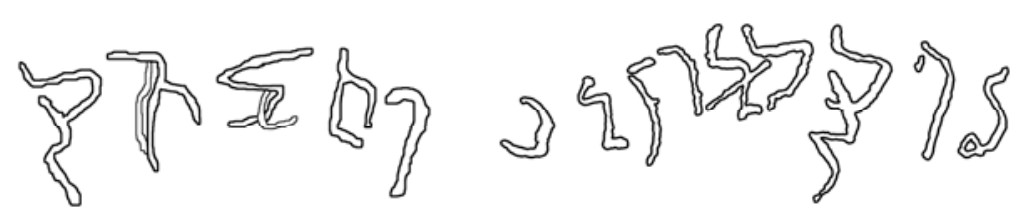

Fig. 1. Drawing of the letters aprakhrakasa and duasatatiśadama.

More important for the present study are the following words, where instead of a barely comprehensible duasya [s]atriena trama I read the required ordinal number dua-satatiśadama, "(one) hundred and seventy-two".

This large discrepancy needs a palaeographical justification. FUSSMAN's sya looks like a sam, but the lower arc is also found elsewhere without being phonetically justified. The $[s] a$ is a clear $t a$; the $t r i$ is a $\underline{t} i$, with underline as in all other occurrences; the $-i$ stroke is misplaced here as in pratithapida earlier; $e-n a$ is a sa written in two movements resulting in two hooks facing each other, and tra is a $\underline{d} a$.

This reading must be compared with the first text. There is a time difference of just 16 years. Nowhere else do we find the ordinal 'hundred' as plain śadama, with $d$ and no apparent locative ending, as otherwise in satame or satamae, satamaye. If this was not the same scribe as the one responsible for the outside, the second one came from the same school as the first. The numbers make the succession of both texts absolutely clear: the outside of the lid came first in year 156, followed by the inside of the body of the reliquary in year 172 .

The complete second inscription on this reliquary reads and translates in my view:

4 There is the possibility that aprakhaka stands for apraksaya, 'Without defeat', similar in meaning to the attested ajita. 
1: ime bhagavato śarira pratithapita sava-budhana puyae aprakhrakasa(?) heliuphila-putrasa

2: dua-satati-śadama gurpiya yambulima mașa saste 4-4

"These relics of the Lord are (deposited) in veneration of all the Buddhas, (as a pious donation) of Aprakhraka?, son of Heliophilos; one-hundred-seventy-second (year), intercalary month Gorpiaios, day 8."

It remains to define the era used. FUSSMAN and all who followed him opted for the Azes era for the first inscription. The same era should apply to year 172 as well.

It seems easier to supply a standard danamukhe for the genitive of the donor than to link the date with the "son of Heliophilos". In the latter case we would get a person responsible for the introduction of the era, so that Azes would appear as the "son of Heliophilos", which presently seems difficult to imagine.

\section{The Macedonian Date}

While a number of Kharosthī and Bactrian inscriptions include dates using Macedonian month names, ${ }^{5}$ the second date in the Trașaka reliquary, year 172 Gorpiaios embolimos 8 , is unique in that the month is intercalary. ${ }^{6}$ It provides an opportunity to date the inscription, and to determine the epoch of its era, by comparing it to intercalary years in other Macedonian calendars.

Three distinct variants of the lunar Macedonian calendar are known. ${ }^{7}$ The most extensively documented, and the most idiosyncratic, is the Macedonian calendar of Ptolemaic Egypt, but this variant is not relevant here. In Seleucid territories, the Macedonian year was aligned with the Babylonian year such that Dios,

5 The months of the Macedonian year, in order, are: Dios, Apellaios, Audnaios, Peritios, Dystros, Xandikos, Artemisios, Daisios, Panemos, Oloios, Gorpiaios and Hyperberetaios.

6 The known Macedonian dates are listed in table 1 on page 210.

7 SAMUEL 1972: 139-151; BENNETT forthcoming. 
the first Macedonian month, usually fell in Tashritu, the seventh Babylonian month. ${ }^{8}$

The Babylonian year began in the spring, close to the vernal equinox, and the calendar was intercalated in 7 years of a 19 year cycle. In six of the seven intercalary years, the intercalary month followed the last ordinary month of the year as Addaru II. In the seventh, it was inserted after the sixth month, as Ululu II. It is generally held that the Seleucid Macedonian calendar was intercalated on the same cycle, though the available evidence, both from Seleucid territories and from Macedonia itself, suggests that the start of the year was actually kept close to the fall equinox. This results in an intercalary cycle which is usually aligned to the Babylonian cycle but is occasionally out of phase with it. ${ }^{9}$ In this scheme, intercalations occurred after Xandikos (= Addaru) and after Hyperberetaios (= Ululu), often, though not always, coincident with Babylonian intercalations.

The third variant was used in Arsacid territories at least as early as 48/7 BC. ${ }^{10}$ Like the second, it was aligned with the Babylonian calendar, but with a shift of one month: Dios fell in Arahsamnu rather than Tashritu. ${ }^{11}$ The available intercalary evidence is consistent with the view that the Arsacid Macedonian year was exactly

8 The months of the Babylonian year, in order, are: Nisannu, Aiaru, Simanu, Du'zu, Abu, Ululu, Tashritu, Arahsamnu, Kislimu, Tebetu, Shabatu and Addaru.

9 This question is explored in more detail in BENNETT forthcoming.

10 The earliest documented intercalary month in the Parthian Macedonian calendar is given by a tetradrachm of Orodes II with the date stamp ГОР EM TI (ASSAR 2003: 178, 182). While the year is not given, other coins datestamped with embolismic months, including one explicitly datestamped as Dystros Embolimos in SEM $317=$ A.D. 5/6 and another as Gorpiaios Embolimos in SEM $360=$ A.D. 48/9, cover eight different intercalary years, matching six of the seven intercalary years of the Babylonian cycle. This dates the embolismic tetradrachm of Orodes II to $48 / 7 \mathrm{BC}$, the only intercalary year in his reign with a Gorpiaios embolimos on that cycle.

11 The shift is proven by a horoscope from Dura Europos dated SEM 487 Panemos 9, with planetary positions corresponding to 2-4 July AD 176 (NEUGEBAUER \& VAN HoESEN 1959, no 176). It is debatable whether the shift caused the start of the year to be moved from Dios to Hyperberetaios. 
aligned to the Babylonian calendar, i.e., six of the seven intercalary months followed Dystros (= Addaru) while the seventh followed Gorpiaios (= Ululu). In this scheme, Gorpiaios embolimos (= Ululu II) occurs only once in every 19 year cycle. ${ }^{12}$

If there was ever any doubt that the Bactrian Greeks used a Macedonian calendar, it was put to rest by the publication of a tax receipt dated to Oloios in year 4 of Antimachos (REA, SENIOR \& HoLLIS 1994). That a Macedonian calendar was used under the Indo-Scythians, the Indo-Parthians and the Kushans is also beyond doubt. The 14 known Macedonian dates cover 8 month names, and the reliquary of Trasaka uses the Greek term embolimos (yambulima) for an intercalation. Until now, the specific variety of Macedonian calendar has not been clear. PINGREE assumed that it was the Seleucid calendar, but with the year realigned to start in spring, in Artemisios (PINGREE 1982: 355). RAPSON assumed that the Macedonian month and era of the Patika copper plate inscription was Parthian (RAPSON 1922: 570). On circumstantial grounds we might suppose that the Bactrian Greeks used the Seleucid calendar, though they certainly abandoned the Seleucid era. ${ }^{13}$ Equally, we might suppose, with RAPSON, that the Indo-

12 While the dated Parthian coinage clearly shows that Macedonian years in the Seleucid era started in the autumn under the Arsacids, Macedonian dates doubled-dated in the Arsacid and Seleucid (SEM) eras show that the Arsacid year number was sometimes 64 years behind the corresponding SEM year number and sometimes 65. ASSAR (2003: 171) suggests this discrepancy results from an Arsacid year starting in the spring following the start of a Seleucid Macedonian year, aligned with the Babylonian year. This most probably indicates that these Macedonian dates are Greek representations of Babylonian dates, cf. Berossus ( $F G r H ~ 3 C 1,680 . F 2)$ and the three "Chaldean" observations in the Almagest (IX.7, XI.7) dated by Macedonian months but Babylonian Seleucid era year numbers. In any case, for the purposes of this paper, it is safe to assume a conventional autumn-based Macedonian year in Arsacid territories; the argument is unaffected.

13 The name of the Yavana Era most likely indicates a Bactrian origin. Known Bactrian Greek year numbers include the regnal year 4 of Antimachos I noted above, a year 24 found at Aï Khanum, conjecturally attributed to (an era of?) Eucratides I (BERNARD 1985: 97-105), and a tax receipt of a king Antimachos dated year 30 (CLARYSSE \& THOMPSON 2007). It is likely that years 47, 48, 57 and 83 of the Yavana Era are documented in coinage (ERRINGTON \& CURTIS 2007: 51, 53). 
Scythians, Indo-Parthians and the Kushans used the Parthian Macedonian calendar in light of their Parthian background and the close connections between them. ${ }^{14}$

Before FUSSMAN's publication of the Trasaka reliquary, the only calendrical evidence on the point was the appearance of the Babylonian months Ululu, in the Laghman II inscription of Aśoka (DAVARY \& HUMBACH 1974: 11), and Nisannu, in the Surkh Kotal inscription SK4 of Kaniska year 31 (GERSHEVITCH 1979: 64), to which we may now add FALK's reading above of year 156 Aiaru 23 in the first inscription of the Trasaka reliquary. These dates imply that the Bactrian calendar remained closely tied to the Babylonian calendar, established under the Achaemenids. The Gorpiaios embolimos of the Trasaka reliquary demonstrates that the Macedonian calendar it used followed the Arsacid rather than the Seleucid solar alignment. The obvious inference, that Trasaka's calendar was the Arsacid Macedonan calendar, governed by the Babylonian intercalary cycle, receives additional support from the likely significance of the date. In that calendar, Gorpiaios embolimos is a month which only appears once every 19 years, and the eighth day is, within a day or two, the date of the fall equinox, a particularly auspicious date. ${ }^{15}$

The era of the inscription is not named. The era of Kaniska, now dated by FALK with a high degree of likelihood to AD 127/8 (FALK 2001, 2004), is too late on paleographic and linguistic grounds, and is anyway excluded because the year number exceeds $100 .{ }^{16}$ The two other eras that were certainly in use are the era of Azes and the Yavana era as found on the Rukhuna reliquary. ${ }^{17}$ The

14 Most recently, FALK 2006: 396-401.

15 NeugEBAuER 1948 describes the theory of solstices and equinoxes in the Babylonian calendar.

16 The system of "dropped hundreds" was first presented by J. VAN LOHUIZENDE LEEUW in 1949 and suitably summarized in 1986. Without this system the two Kaniskas melted into one, and Vasiska had his place between Kanișka I and Huvișka, instead of after Kaniska II, not to speak of arthistorical confusion. Some criticism is listed FALK 2004.

17 Since the term yavana was applied to western foreigners in general it does not follow that this yona era is the one found on the Maghera pedestal 
linguistic comparisons published by SALOMON to other reliquaries, including one explicitly dated to 126 Azes, suggest that the Azes era is the most likely (SALOMON 1995: 130).

The Rukhuna reliquary, dated to 201 Yavana $=73$ Azes, Śrāvana 8, proves that the era of Azes began 128 years after the era of the Yavanas (SALOMON 2005). The era of Azes is widely assumed to be the same as the later Vikrama era, starting in 58/7 BC, which dates the epoch of the era of the Yavanas to 186/5 BC. However, if this inscription uses the Arsacid Macedonian calendar, its epoch cannot fall in either year. Year 172 falls exactly 9 cycles of 19 years after year 1 . Therefore the era began in a Parthian Macedonian year that was also intercalary in Gorpiaios. While 186/5 and 58/7 were both intercalary Macedonian years, neither of them meets this constraint. As we have seen above, six of the seven intercalary years in the 19 year intercalary cycle have intercalary months after Dystros. The expected intercalary month for both 186/5 and 58/7 is Dystros embolimos, and this is also the latest possible position which preserves the correct alignment of the Macedonian year at the start of the next spring-based year on the Babylonian cycle.

The assumption that the Azes era is the same as the Vikrama era ultimately depends on Occam's Razor: the two eras certainly began around the same time, so the simplest model, in the absence of contrary evidence, is that they are two names for the same era. ${ }^{18}$ Some credibility is perhaps given by the fact that the name of the Vikrama era demonstrably changed from time to time. ${ }^{19}$ However,

(FUSSMAN 1993: 113), which is dated to the year 116 during the reign of a yavana king (yavanarājya), most likely Azes himself.

18 SALOMON 2005: 369: "Ultimately, the strongest point in favor of the equation of the Azes and Vikrama eras is that, if it is not accepted, we are left without a good explanation of the historical origin of the latter in 58/7 B.C."; cf. already KonOw 1929: 1xxxvii: "The chief reason for referring the older Kharoshthī records to the Vikrama era seems to be that it seems necessary to assume an epoch in the first century B.C., as is the case with the Vikrama Samvat, and most scholars are disinclined to assume the existence of two eras beginning at about the same time." SALOMON accepts the assumption; KonOw rejected it, though he later changed his mind.

19 SALOMON 1982: 65-67; the era is provably traceable to the krta year $282=$ AD 225/6. 
the example of the Kaniska era, long identified by many scholars with the Saka era of AD 78/9 on similar grounds, demonstrates the risk of over-reliance on such reductionist reasoning, and the date we are now considering creates a reductionist dilemma: we can only minimize the number of eras by postulating the existence of an otherwise-unknown variant of the Macedonian calendar, else we must admit the existence of an era close in time but distinct from the Vikrama era in order not to do so.

Explicit mentions of the Azes era are now known from several inscriptions ranging in date from year 9 to year $136,{ }^{20}$ and inscriptions of years 156 and 157 are safely assigned to that era. ${ }^{21}$ There is no doubt that the era was established by Azes himself, although it need not celebrate his accession. ${ }^{22}$ We have two items allowing us to establish an approximate timeframe for its epoch. The first is the Takht-i-Bāhī inscription equating year 26 of Gondophares with year 103 of an unspecified era (KoNOw 1929: 57-62). Assuming that there is a historical basis for the wellknown story that St Thomas visited the court of Gondophares, he must have reigned within a generation of the crucifixion, and the epoch of the Takht-i-Bāhī era must fall in the middle decades of the first century BC. Since the sequence of rulers from Azes I to Gondophares is fairly well-established on numismatic grounds, this range matches the likely dates of Azes himself. The second is the Dasht-i-Nāwur inscription dated year 279 Gorpiaios 15 under the Kushan king Vima Takhto (FUSSMAN 1974), who is now known from the Rabatak inscription to be Kaniska's grandfather (SIMS-WILliams 2004). Allowing at least $c a .15$ years for Vima Kadphises, ${ }^{23}$ the epoch of the era of Dasht-i-Nāwur must be no

20 Year 9: FALK 2006; year 136: KonOw 1929: 70-77.

21 Year 156 (the first date of the present inscription): FUSSMAN 1985 corrected by SALOMON 1995: 130; year 157: SALOMON 1995.

22 FALK 2006: 397 and 2009: 71 suggests the possibility that a unification of several competing powers led to a sort of "pax Aziana", deserving to be commemorated as the starting-point of an era.

23 This includes the Khalatse inscription mentioning Vima Kadphises with a date of 287, as proposed by CRIBB; cf. SALOMON 2005: 376 . The reading of Surkh Kotal inscription SK2 given in HARMATTA 1992: 427, year 299 Dios 19 under Vima Kadphises, if accepted, would add 5 years to this calculation, 
later than $c a .165 \mathrm{BC}$. Assuming this to be the Yavana era, the epoch of the Azes era must be not later than $c a .40 \mathrm{BC}$.

Following the intercalary cycle described above, there are two years in the Parthian Macedonian calendar in the mid-first century BC with a Gorpiaios embolimos: 67/6 BC and 48/7 BC. Macedonian years began in autumn, while the Rukhuna reliquary most likely gives a month in a spring-based year, ${ }^{24}$ so there is a potential ambiguity of half a year if we use autumn-based years for calculations. Since Gorpiaios embolimos is the same month as Ululu II, we may avoid this difficulty by using the corresponding Babylonian years as the candidate epochs: $66 / 5 \mathrm{BC}$ (= year 182 in the Arsacid era [AE]) and 47/6 BC (= AE 201). If we equate 66/5 $\mathrm{BC}$ to 1 Azes, it follows that the Rukhuna reliquary dates to $\mathrm{AD}$ 7/8, 1 Yavana $=194 / 3 \mathrm{BC}$, and 1 Kanișa $=\mathrm{AD} 127 / 8=321$ Yavana. If we equate $47 / 6 \mathrm{BC}$ to 1 Azes, it follows that the Rukhuna reliquary dates to $\mathrm{AD} 26 / 7,1$ Yavana $=175 / 4 \mathrm{BC}$, and 1 Kaniska $=$ AD 127/8 = 302 Yavana.

We can decide between these alternatives. CRIBB has recently conjectured that the Kaniska era began at the start of the fourth century of the Yavana Era. ${ }^{25}$ It appears we have shown that the

but it seems hard to square it with the photograph in BIVAR 1963: plate I, and it has been generally ignored for good reasons.

24 The astronomical analyses of the inceptions of the yuga of Sphujiddhvaja in AD 22/3 and the Śaka era in AD 78/9 presented in FALK 2001 show that both began with the first new moon after the vernal equinox. The months of the Indian year are, in order, Caitra, Vaiśākha, Jyaiștha, Āsāâha, Śrāvana, Bhādrapada, Āśvina, Kārttika, Mārgaśīrṣa, Pauṣya, Māgha and Phālguna. Nakșatra data from inscriptions of the Azes era show that amānta and pürnimānta Indian months were both used (FALK forthcoming).

25 CRIBB 2005: 214; ERRINGTON \& CURTIS 2007: 55, 67. CRIBB's discussion assumes that the anonymous maharaja rajatiraja of the Mathura inscription of 299 (or 292) was Vima Kadphises, rather than Kaniska before the introduction of his era, and gives no reason to suppose that the apparent discontinuation of the Yavana era in royal inscriptions is anything more than an interesting coincidence due to lack of evidence. It is agreed (SALOMON 2005: 377; ERRINGTON \& CURTIS 2007: 53, 54) that there are fourth century Yavana dates in private inscriptions. A different problem is that Kaniska "inaugurated the year one", according to SIMS-WILLIAMS (2004), where voß $\alpha \sigma \tau$ is defined as "inaugurated" only on account of the context. The 
epoch is at least a year later. However, these calculations are for years beginning in spring, while the Yavanas, Bactrian Greeks, certainly used the Macedonian calendar as their native calendar, so their year certainly started in the autumn. Just as the Macedonian year overlaps two spring-based Babylonian years by roughly equal amounts, it also overlaps two spring-based Indian years. Even if the Arsacid Babylonian year started half a year after the corresponding Arsacid Macedonian year, following the Seleucid precedent, there is no reason to suppose that a spring-based Indian year of the Yavana era followed the same rule. If we suppose instead that the Indian Yavana year started half a year before the beginning of the corresponding Yavana Macedonian year, it follows from 1 Azes $=47 / 6 \mathrm{BC}$ (spring-based) that 1 Kaniska in the Indian calendar began in the last half of 301 Yavana (Macedonian).

The Macedonian date of the Trasaka reliquary thus adds weight to CRIBB's conjecture. FALK has suggested that the use of dropped hundreds in Kushan date reckoning was inspired by the Roman saeculum (FALK 2001, 2004). The interest in centenaries now appears to be considerably older. If the epoch of the era of Azes was $47 / 6 \mathrm{BC}=\mathrm{AE} 201$, this era was itself was the second centennial of the Arsacid era. These associations seem unlikely to be coincidental, and may well have been the occasion for starting a new era in each case. These considerations favor choosing 47/6 BC over 66/5 BC for the start of the Azes era, and suggest that the Kushan Macedonian year began before the corresponding Indian year. They also suggest that the epochs of the eras of Azes and Kaniska may not be their first regnal years.

We can with some confidence equate the date of 172 Gorpiaios embolimos 8 in the second inscription of the "Trasaka" reliquary to 24 September AD 125. The era started in spring of $47 \mathrm{BC}$ or autumn $48 \mathrm{BC}$, and is most likely the Azes era. The date is the highest yet known in that era. It is far from arbitrary, being the date of the fall equinox, probably marking the end of the ninth intercalary cycle and the start of the tenth. If the era is correctly

alleged formal parallels, however, all show an $i$ as the first vowel. Wouldn't "renewed" be more probable? 
assigned, it shows that both the Azes and the Kanișka eras began as centennial cycles of the earlier Arsacid and Yavana eras, and that the origins of the Vikrama era again must be sought elsewhere.

Table 1: Catalogue of Macedonian Dates in Kharoșțī, Bactrian and Brāhmī Inscriptions

\begin{tabular}{|c|c|c|c|c|}
\hline No. & $\begin{array}{c}\text { Julian } \\
\text { Year } \\
\text { (A.D.) }\end{array}$ & $\begin{array}{c}\text { Date } \\
\text { year month day }\end{array}$ & Era & Publication \\
\hline 1 & $12 / 13$ & 60 Xandikos 15 & [Azes] & SALOMON 2000 \\
\hline 2 & $<30 / 31$ & 78 Panemos 5 & [Maues?] & KoNOW 1929: XIII \\
\hline 3 & $35 / 36$ & 83 Oloios 1 & [Azes?] & FALK 2006: 408 n. 39 \\
\hline 4 & $103 / 4$ & 279 Gorpiaios 15 & [Yavana] & FUSSMAN 1974 \\
\hline 5 & $124 / 5$ & $\begin{array}{l}172 \text { Gorpaios } \\
\text { embolimos } 8\end{array}$ & [Azes] & $\begin{array}{l}\text { FUSSMAN 1985; } \\
\text { [current paper] }\end{array}$ \\
\hline 6 & $137 / 8$ & 11 Daisios 28 & Kanișka & KoNOW 1929: LXXIV \\
\hline 7 & $138 / 9$ & 12 Audnaios 5 & [Kanișka] & SALOMON 2003 \\
\hline 8 & $144 / 5$ & 18 Artemisios 10 & Kaniṣka & KONOW 1929: LXXIX \\
\hline 9 & $146 / 7$ & 20 Audnaios 20 & Kaniṣka & KonOw 1929: LXXX \\
\hline 10 & $146 / 7$ & 20 Oloios 30 & [Kanișka] & FALK 2003 \\
\hline 11 & $154 / 5$ & 28 Apellaios 10 & Kaniṣka & KONOW 1929: LXXXII \\
\hline 12 & $154 / 5$ & 28 Gorpiaios 1 & Kanișka & KonOw $1931 / 2$ \\
\hline 13 & $165 / 6$ & 39 Audnaios 13 & [Kanișka] & SALOMON 1981 \\
\hline 14 & $177 / 8$ & 51 Artemisios 15 & Kanișka & KONOW 1929: LXXXVI \\
\hline
\end{tabular}

\section{Results}

A comparison of the single Macedonian intercalary date from Gandhara with Macedonian calendars outside Gandhara has shown that the most likely model used in Gandhara was the Arsacid calendar. This date of Gorpiaios 172 is not intercalary (embolimos/yambulima) when based on an Azes era which is identical with the Vikrama samvat era. Within the range of possible dates, a Gorpiaios embolimos is found in AD 124/5 according to the Macedonian calendar of the Arsacids. Starting from here, the epoch of the era of Azes shifts to 48/7 (spring-based year) or 47/6 BC (autumn-based year).

Since the difference between the Azes and Yavana eras is known to be 128 years in spring-based calendars, and since the 
Yavana Macedonian year was behind the Yavana Indian year, the epoch of the era of the Yavanas has to move too and lands in BC $175 / 4$, almost exactly as estimated by CRIBB and ERRINGTON on other grounds. The difference of one year can be accounted for by the interaction of spring-based Indian years and autumn-based Macedonian years.

It is hardly coincidental that Kaniska's year 1 is now identical with year 301 in the Yavana era, and that year 1 of Azes is year 201 in the Arsacid era. Both "new" eras thus are nothing but continuations of older traditions. Seen this way, year 1 of Kaniska need not define his first year in power; likewise, year 1 of Azes could be placed anywhere in his reign.

Dates in the Azes era use a mixture of Iranian and Indian terms, whereas the Kusāanas prefer Macedonian terms throughout, both in their era and in month names.

While the origin of the Arsacid reckoning is known, the start of the yavana era can now be evaluated anew. We leave it to the historians and numismatists to propose the most likely explanations. 


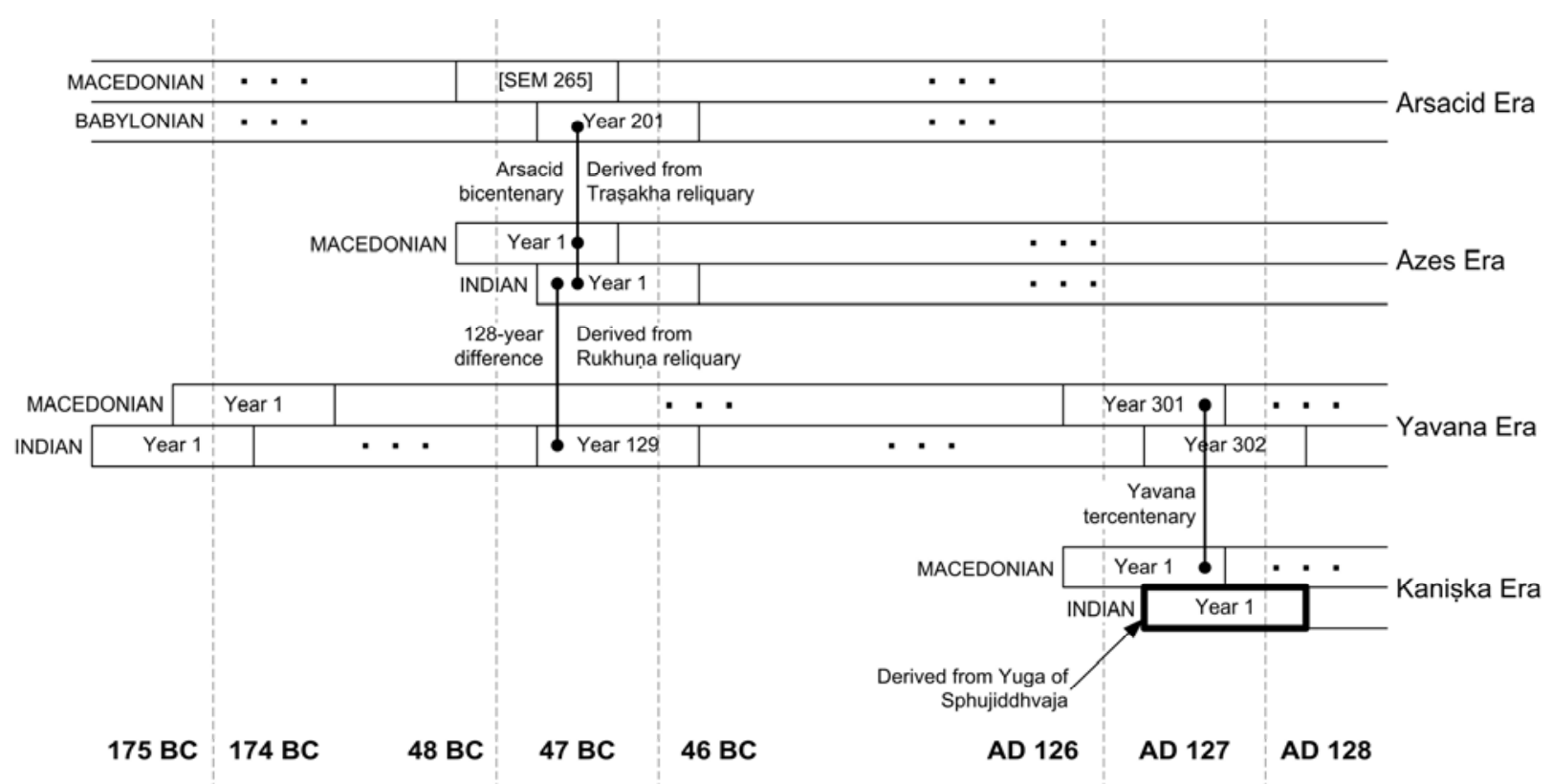

Fig. 2. Synoptical chart of the four eras concerned with points of interlinkage 


\section{Bibliography}

ASSAR, G. R. F (2003), Parthian Calendars at Babylon and Seleucia on the Tigris. Iran 41: 171-191.

BAUMS, S. (2006), Bemerkungen zum Ordinalzahlsystem der Gāndhārī. U. Hüsken, P. Kieffer-Pülz \& A. Peters (eds.), Jaina-Itihāsa-Ratna - Festschrift für Gustav Roth zum 90. Geburtstag (Indica et Tibetica, 47), pp. 33-44. Marburg.

BAILEY, H. W. (1978), Two Kharostị Casket Inscriptions from Avaca. Journal of the Royal Asiatic Society 1978: 3-13.

BennetT, C. J. (forthcoming), Alexandria and the Ptolemaic Macedonian Calendar (Studia Hellenistica). Leuven.

BERNARD, P. (1985), Fouilles d'Aï Khanoum IV: Les monnaies hors trésors; questions d'histoire gréco-bactrienne. Paris.

BIVAR, A. D. H. (1963), The Kanishka Dating from Surkh Kotal. Bulletin of the School of Oriental and African Studies 26: 498-502.

_ (1981), The Azes Era and the Indravarman Casket. H. Härtel (ed.), South Asian Archaeology 1979: Papers from the Fifth International Conference of the Association of South Asian Archaeologists in Western Europe Held in the Museum für Kunst der staatlichen Museen preussischer Kulturbesitz Berlin, pp. 369-376. Berlin (Dietrich Reimer).

BopeARACHCHI, O. \& BROUSSAC, M.-F. (2005), (eds.), Afghanistan: ancien carrefour entre l'est et l'ouest (Indicopleustoi, 3). Turnhout: Brepols.

Clarysse, W. \& THOMPson, D. J. (2007), Two Greek Texts on Skin from Hellenistic Bactria. Zeitschrift für Papyrologie und Epigraphik 159: 273-279.

CRIBB, J. (2005), The Greek Kingdom of Bactria, Its Coinage and Its Collapse. In BOPEARACHCHI \& BROUSSAC 2005: 207225.

DAVARY, G. D. \& H. HUMBACH (1974), Eine weitere aramäoiranische Inschrift der Periode des Aśoka aus Afghanistan. Wiesbaden.

ERrington, E. \& V. S. CURTIS (2007), From Persepolis to Punjab: Exploring Ancient Iran, Afghanistan and Pakistan. London. 
FALK, H. (2001), The yuga of Sphujiddhvaja and the Era of the Kusânas. Silk Road Art and Archaeology 7: 121-136.

(2003), Five New Kharosthī Donation Records from Gandhāra. Silk Road Art and Archaeology 9: 71-86.

(2004), The Kanișa Era in Gupta Records. Silk Road Art and Archaeology 10: 167-176.

— (2006), Three Inscribed Buddhist Monastic Utensils from Gandhāra. Zeitschrift der Deutschen Morgenländischen Gesellschaft 156: 393-412.

- (2009), Gandharan Eras. Gandhara - The Buddhist Heritage of Pakistan - Legends, Monasteries, and Paradise, pp. 7071. Mainz: Philipp von Zabern.

— (forthcoming), Signature Phrases in Buddhist Reliquary Donation Records.

FUSSMAN, G. (1974), Documents epigraphiques kouchans. Bulletin de l'École Française d'Extrême Orient 61: 1-75.

- (1980), Nouvelles inscriptions śaka: Ère d'Eucratide, Ère d'Azès, Ère Vikrama, Ère de Kanișka. Bulletin de l'École Française d'Extrême Orient 67: 1-44.

- (1985), Nouvelles inscriptions Śaka (III). Bulletin de l'École Française d'Extrême Orient 74: 35-42.

(1993), L'indo-grec Ménandre ou Paul Demiéville revisité. Journal Asiatique 281: 61-138.

GERSHEVITCH, I. (1979), Nokonzok's Well. Afghan Studies 2: 5573.

HARMATTA, J. (1992), Languages and Literature in the Kushan Empire. A. H. Dani et al., History of Civilizations of Central Asia, pp. 417-440. Paris.

KonOw, S. (1929), Kharoshthi Inscriptions, with the Exception of Those of Aśoka (Corpus Inscriptionum Indicarum II.I). Calcutta.

— (1931/32), Mathura Brāhmī Inscription of the Year 28. Epigraphia Indica 21: 55-61.

MARShall, J. H. (1914), The Era of Kanishka. Journal of the Royal Asiatic Society 1914: 973-986.

Neugebauer, O. (1948), Solstices and Equinoxes in Babylonian Astronomy during the Seleucid Period. Journal of Cuneiform Studies 2: 209-222. 
Neugebauer, O. \& H. B. VAN Hoesen (1959), Greek Horoscopes (Memoirs of the American Philosophical Society, 48). Philadelphia.

PINGREE, D. (1982), A Note on the Calendars Used in Early Indian Inscriptions. Journal of the American Oriental Society 102: 355-359.

RAPSON, E. J. (1922), The Scythian and Parthian Invaders. E. J. Rapson (ed.), The Cambridge History of India I: Ancient India, pp. 563-592. Cambridge.

REA, J. R, SENIOR, R. C. \& A. S. Hollis (1994), A Tax Receipt from Hellenistic Bactria. Zeitschrift für Papyrologie und Epigraphik 104: 261-280.

SALOMON, R. (1981), The Spinwam (North Waziristan) Kharosthth Inscription. Studien zur Indologie und Iranistik 7: 11-20. (1982), The 'Avaca' Inscription and the Origin of the Vikrama Era. Journal of the American Oriental Society 102: 59-68.

(1995), Three Dated Kharoșthī Inscriptions. Bulletin of the Asia Institute 9: 127-141.

(2000), Two New Kharosthīi Inscriptions. Bulletin of the Asia Institute 14: 55-68.

- (2003), The Senior Manuscripts: Another Collection of Gandharan Buddhist Scrolls. Journal of the American Oriental Society 123: 73-92.

- (2005), The Indo-Greek era of 186/5 in a Buddhist Reliquary Inscription. In: BOPEARACHCHI \& BROUSSAC 2005: 359401.

Samuel, A. E. (1972), Greek and Roman Chronology: Calendars and Years in Classical Antiquity (Handbuch der Altertumswissenschaft, 7). Munich.

SIMS-WILLIAMS, N. (2004), The Bactrian Inscription of Rabatak: A New Reading. Bulletin of the Asia Institute 18: 53-68.

VAN LOHUIZEN-DE LEeUW, J. E. (1949), The "Scythian" Period. An Approach to the History, Art, Epigraphy and Palaeography of North India from the 1st Century B.C. to the 3rd Century A.D. Leiden. 
(1986), The Second Century of the Kaniska Era. South Asian Studies 2: 1-9. 